\title{
Decreased c-Abl activity in PC-3 and LNCaP prostate cancer cells overexpressing the early growth response-1 protein
}

\author{
EDUARDO PARRA $^{1}$, JORGE FERREIRA $^{2}$ and LUIS GUTIERREZ ${ }^{3}$ \\ ${ }^{1}$ Laboratory of Experimental Biomedicine, University of Tarapaca, Campus Esmeralda, Iquique; \\ ${ }^{2}$ Programme of Molecular and Clinical Pharmacology, ICBM, Medical Faculty, University of Chile, Santiago; \\ ${ }^{3}$ Faculty of Sciences, Arturo Prat University, Iquique, Chile
}

Received July 19, 2013; Accepted September 27, 2013

DOI: $10.3892 /$ or.2013.2829

\begin{abstract}
Early growth response-1 (Egr-1) and the non-receptor protein tyrosine kinase $(\mathrm{c}-\mathrm{Abl})$ are 2 response genes that can act as regulators of cell growth and apoptosis in response to stress. Both Egr-1 and c-Abl regulate cell proliferation and survival in different types of cancer cells. To study the effect of overexpression of EGR-1 on the activity of c-Abl in prostate cancer cells, human PC-3 and LNCaP cells were transfected with a control vector or a vector containing the murine Egr-1 cDNA and assessed for the expression of the c-Abl gene. Cells overexpressing Egr-1 were studied with respect to apoptosis (Annexin V)/DEVDase activity, Egr-1/c-Abl activation (western blotting) and cell proliferation (MTT assay). The cells were exposed to tumor necrosis factor $\alpha$ (TNF- $\alpha$ ), a known inductor of Egr-1, to c-Abl inhibitor STI-571 and to small interfering RNA (siRNA)-Egr-1, respectively. The results from our studies strongly suggest that overexpression of Egr-1 decreased c-Abl activity independent of endogenous Egr-1 inhibition by siRNA-Egr-1.
\end{abstract}

\section{Introduction}

Prostate cancer is the most prevalent malignancy and the second leading cause of cancer-related mortality in men (1-3). One protein that plays a crucial role in development and progression of prostate cancer is the early growth response-1 (EGR-1) which is a member of the immediate early gene family and encodes a nuclear phosphoprotein involved in the regulation of cell growth and differentiation in response to signals such as mitogens, growth factors and stress stimuli (4-9). However, in other circumstances, EGR-1 is induced very early in the apoptotic process $(10,11)$, where it mediates the activation of downstream

Correspondence to: Dr Eduardo Parra Villegas, Laboratory of Experimental Biomedicine, University of Tarapaca, Campus Esmeralda, Avenida Luis Emilio Recabarren 2477, Iquique, Chile E-mail: eparra@uta.cl

Key words: PC-3/LNCaP, early growth response-1, c-Abl, apoptosis regulatory genes (8-10). It has been previously demonstrated that EGR-1 is required for tumor formation by a variety of human cancers (12). Another protein that recently has been involved in cancer progression is the cellular-Abelson tyrosine kinase (c-Abl), a 140-kDa proto-oncoprotein non-receptor tyrosine kinase (13) that is activated by diverse genotoxic agents inducing apoptosis (14). The mechanisms responsible for nuclear targeting of c-Abl remain unclear, but cytoplasmic c-Abl is targeted to the nucleus following a DNA damage response $(14,15)$. c-Abl has been shown to regulate the cell cycle and to induce, under certain conditions, cell growth arrest and apoptosis $(14,16)$. It has been demonstrated that c-Abl regulates EGR-1 protein in response to oxidative stress (17). In addition, c-Abl-induced apoptosis is partially mitigated by EGR-1 activity, as cells devoid of EGR-1 expression undergo reduced rates of c-Abl-induced apoptosis (17). Recent studies provide evidence that implicates $\mathrm{c}-\mathrm{Abl}$ as a mediator of fibrotic responses induced by transforming growth factor- $\beta$ (TGF- $\beta$ ), yet the precise mechanisms underlying this novel oncogene function are unknown (18). However, c-Abl has also been proposed to play a role in cell cycle progression via interaction with $\mathrm{Rb}$ (19), and observations have implicated c-Abl in the process of apoptosis (20-23). Most importantly, c-Abl is activated by DNA-damaging agents but not by UV radiation, suggesting that it is unlikely that p53 is involved in the c-Abl-induced apoptosis pathway. In addition, EGR-1 overexpression is correlated with loss of its co-repressor NAB2 in primary prostate carcinoma $(24,25)$. Recently, we demonstrated that overexpression of EGR-1 modulates the activity of NF- $\kappa \mathrm{B}$ and AP-1 in prostate cancer cell lines (9), while inhibition of Egr-1 by small interfering RNA (siRNA) was able to decrease the expression and activity of NF- $\kappa \mathrm{B}$ and AP-1 $(8,9)$. Therefore, overexpression of EGR-1 appears to be an important mechanism for the modulation of several types of cell responses. To investigate the effect of the overexpression of EGR-1 on the expression and activity of c-Abl, PC-3 and LNCaP prostate carcinoma cell lines were transfected with an Egr-1 expression plasmid and clones overexpressing EGR-1 were obtained. We showed that overexpression of Egr-1 modulates the normal activity and expression of c-Abl and inhibits the proapoptotic property of this kinase, consequently promoting cell growth, independent anchorage and survival of cells. In conclusion, the results suggest that overexpression of EGR-1 inhibits the pro-apoptotic function of c-Abl similarly in both wild-type 
p53 (LNCaP) and p53-deficient (PC-3) prostate carcinoma cell lines.

\section{Materials and methods}

Cell lines and culture. Human prostate carcinoma cell lines PC-3 and LNCaP were a gift from Dr Dan Mercola (The SKCC, La Jolla, CA, USA). The cells were cultured in RPMI-1640 medium supplemented with $100 \mathrm{ml} / \mathrm{l}$ fetal bovine serum (FBS), $8 \times 10^{5} \mathrm{U} / 1$ penicillin and $0.1 \mathrm{~g} / 1$ streptomycin in a humidified incubator containing $50 \mathrm{ml} / 1 \mathrm{CO}_{2}$ at $37^{\circ} \mathrm{C}(30-32)$. Tris-borate-EDTA and acrylamide:bisacrylamide (29:1) were obtained from Bio-Rad (Richmond, CA, USA). Egr-1 antibody was purchased from Santa Cruz Biotechnology, Inc. (Santa Cruz, CA, USA). STI571 was kindly provided by Novartis Pharma AG (Basel, Switzerland). Lipofectamine was obtained from Life Technologies, Inc., USA, and TNF- $\alpha$ was purchased from Sigma Chemical Co. (St. Louis, MO, USA). Complete Mini-EDTA-Free Protease Inhibitor Cocktail Tablets and Annexin-V-Fluos were purchased from Roche Diagnostics $\mathrm{GmbH}$ (Mannheim, Germany). All other reagents were from Sigma Chemical Co. (Taufkirchen, Germany).

siRNAs. To generate siRNA/Egr-1, a 19-bp sequence was identified as unique to Egr-1, as determined by BLAST searches of the non-redundant National Center for Biotechnology Information (NCBI) nucleotide databases, and was flanked with 2 adenine ribonucleotides and 2 deoxythymidines. Double-stranded siRNA sequences were as follows: siEgr-1, 5'-AACGCAAG AGGCAUACCAAGAdTdT-3', and 5'-AAUCUUGGUAUGC CUCUUGCGdTdT-3'. Cells were treated in parallel with siRNA-scrambled (5'-AACUCUUCGCCGGUCAUAUCCd TdT-3' and 5'-AAGGAUAUGACCGGCGAAGAGdTdT-3') as the control, and were synthesized by Shanghai GeneChem Co. These cells were cultured in medium without antibiotics and $24 \mathrm{~h}$ before transfection resulting in a confluence of the cell monolayer by $60-80 \%$. Egr-1-siRNA or non-silencing siRNA $\left(70 \mathrm{nmol}\right.$ ) were mixed with Lipofectamine ${ }^{\mathrm{TM}} 2000$ (Invitrogen Life Technologies) according to the manufacturer's recommendation and added to the cells. After $6 \mathrm{~h}$ at $37^{\circ} \mathrm{C}$, the medium was replaced, and the cells were cultivated in RPMI-1640 supplemented with $10 \%$ heat-inactivated FBS $(8,26)$.

Western blot analysis. The prostate carcinoma cell lines PC-3 and LNCaP transfected with the empty vector (pCMV) or with an expression plasmid for Egr-1 (pCMV-Egr-1) $\left(5 \times 10^{5}\right)$ were seeded onto 6-well plates. Forty-eight hours after transfection, cells were collected and washed twice by cold PBS, and each well was treated with $50 \mathrm{ml}$ lysis buffer $[2 \mathrm{mmol} / 1 \mathrm{Tris}-\mathrm{HCl}$ pH 7.4, $50 \mathrm{mmol} / 1 \mathrm{NaCl}, 25 \mathrm{mmol} / \mathrm{l}$ EDTA, $50 \mathrm{mmol} / \mathrm{l} \mathrm{NaF}$, $1.5 \mathrm{mmol} / 1 \mathrm{Na}_{3} \mathrm{VO}_{4}, 1 \%$ Triton X-100, $0.1 \%$ SDS, supplemented with protease inhibitors $1 \mathrm{mmol} / \mathrm{l}$ phenylmethylsulfonyl fluoride, $10 \mathrm{mg} / \mathrm{l}$ pepstatin, $10 \mathrm{mg} / \mathrm{l}$ aprotinin and $5 \mathrm{mg} / \mathrm{l}$ leupeptin (all from Sigma)].Protein concentrations were determined using the Bradford protein assay. Equal amounts of protein $(50 \mu \mathrm{g})$ were separated on a $15 \%$ SDS polyacrylamide gel and transferred to nitrocellulose membranes (Hybond C; Amersham, Freiburg, Germany). Membranes were blocked in 5\% nonfat dry milk in TBS for $1 \mathrm{~h}$ at room temperature and probed with the rabbit anti-Egr-1 antibody (dilution 1:500; Santa Cruz
Biotechnology, Inc.) overnight at $4^{\circ} \mathrm{C}$. After 3 washing with TBS containing $0.1 \%$ Tween-20, membranes were incubated with anti-rabbit IgG-horseradish-peroxidase (1:5,000; Santa Cruz Biotechnology, Inc.) and developed by luminol-mediated chemiluminescence (Appylgen Technologies, Inc., China). To confirm equal protein loading, membranes were reprobed with a 1:1,000 dilution of an anti-actin antibody (Santa Cruz Biotechnology, Inc.). Densitometric analyses were performed using Scion image software $(8,9)$.

Determination of caspase activity. Protein cell extracts were prepared form PC-3 and LNCaP cells treated with either siRNA-Egr-1 or STI-571 in CE buffer (25 mM PIPES pH 7.0, $25 \mathrm{mM} \mathrm{KCl}, 5 \mathrm{mM}$ EGTA, $1 \mathrm{mM}$ DTT, $10 \mu \mathrm{M}$ cytochalasin B, $0.5 \%$ NP-40 and protease inhibitor) and cleared by centrifugation at $20,000 \mathrm{x}$ g for $30 \mathrm{~min}$. Protein $(10-20 \mu \mathrm{g})$ were diluted in a total volume of $500 \mathrm{ml}$ of caspase buffer (50 mM HEPES pH 7.4, $100 \mathrm{mM} \mathrm{NaCl}, 1 \mathrm{mM}$ EDTA, $5 \mathrm{mM}$ DTT, $0.1 \%$ CHAPS and $10 \%$ sucrose) containing $100 \mu \mathrm{M}$ Ac-DEVD-AFC. Reactions were incubated at $37^{\circ} \mathrm{C}$, and the fluorescence at $400 \mathrm{~nm} \mathrm{Ex/505} \mathrm{nm}$ Em was measured every $5 \mathrm{~min}$ for 30-60 min. Caspase activity was calculated from the initial slope of a standard curve with known concentrations of free AFC. Caspase inhibitors were purchased from Enzyme Systems Products (Livermore, CA, USA) (26).

3-(4,5-Methylthiazol-2-yl)-2,5-diphenyltetrazolium bromide (MTT) assay (cell toxicity assay). The effect of blocking c-Abl and/or Egr-1 activity in human LNCaP and PC-3 prostate carcinoma cells was determined by the MTT survival assay, or using a commercial MTT assay kit (CellTiter $96^{\circledR}$ AQueous One Solution Cell Proliferation Assay; Promega Corporation, Madison, WI, USA) according to the manufacturer's instructions. The MTT survival assay was performed as described previously (Yu et al, 2000). The MTT assay is a commonly used method for the evaluation of cell survival, based on the ability of viable cells to convert MTT, a soluble tetrazolium salt [3-(4,5-dimethylthiazole-2-yl)-2,5-diphenyltetrazolium bromide (MTT)], into an insoluble formazan precipitate, which is quantitated by spectrophotometry following solubilization in dimethyl sulfoxide (DMSO). Briefly, LNCaP and PC-3 cells untreated and treated with TNF- $\alpha$ alone, or in combination with siRNA-Egr-1 or STI-571, were cultured in 96-well tissue culture dishes and incubated with MTT $(2 \mathrm{mg} / \mathrm{ml})$ for $4 \mathrm{~h}$. The cells were then solubilized in $125 \mathrm{ml}$ of DMSO, and absorbance readings were taken using a 96-well Opsys $\mathrm{MR}^{\mathrm{TM}}$ microplate reader (Thermo Labsystems, Chantilly, VA, USA). The amount of MTT dye reduction was calculated based on the difference between absorbance at 570 and $630 \mathrm{~nm}$. Cell viability in treated cells was expressed as the amount of dye reduction relative to that of untreated control cells. The wells which contained only medium and $10 \mathrm{ml}$ of MTT were used as blanks for the plate reader.

Cell death assay. Cell death was assessed as previously described (27). Annexin V-fluorescein isothiocyanate (Annexin V-FITC) and propidium iodide (PI) labeling was performed using the Apoptosis/Necrosis Detection kit (Abcam, UK) according to the manufacturer's instructions. After $24 \mathrm{~h}$ of treatment, the cells were harvested and Annexin V-FITC 
A

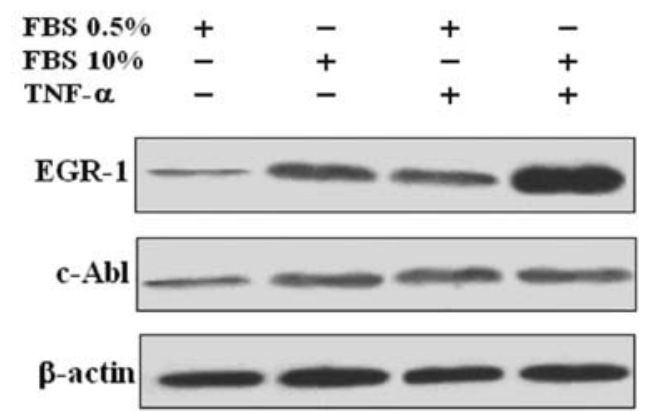

B

$\begin{array}{lllll}\text { FBS 0.5 } & + & - & + & - \\ \text { FBS 10\% } & - & + & - & + \\ \text { TNF- } \alpha & - & - & + & +\end{array}$

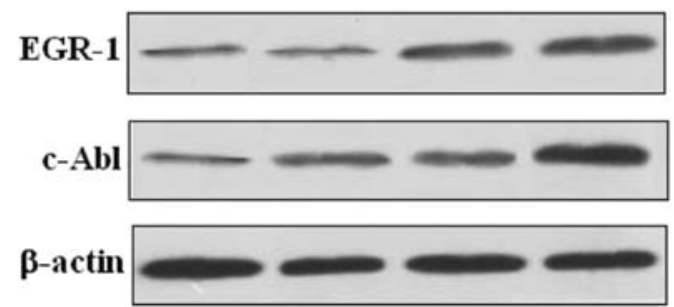

Figure 1. Increasing amount of serum alone or in combination with TNF- $\alpha$, strongly increased the expression of EGR-1 and weakly increased the expression of c-Abl in prostate carcinoma cell lines. (A) PC-3 and (B) LNCaP cells were treated for $24 \mathrm{~h}$ with TNF- $\alpha(20 \mathrm{ng} / \mathrm{ml})$, in medium containing 0.5 or $10 \%$ FBS. Western blot assay was performed to measure the expression of either EGR-1 or c-Abl protein. $\beta$-actin was used as a control protein. The intensity of each band was quantified by densitometer. One of 3 similar experiments is shown. TNF- $\alpha$, tumor necrosis factor $\alpha$; EGR-1, early growth response-1; c-Abl, cellular-Abelson tyrosine kinase; FBS, fetal bovine serum.

was added to a final concentration of $2.5 \mathrm{mg} / \mathrm{ml}$. To detect necrotic cells, PI was added at a concentration of $5 \mathrm{mg} / \mathrm{ml}$. The Annexin V-FITC and PI-labeled cells were analyzed by FACS (FACSCanto; BD Biosciences, San Jose, CA, USA). Using flow cytometry, dot plots of Annexin V-FITC on the x-axis against PI on the $y$-axis were used to distinguish viable cells (negative for both PI and Annexin V-FITC), early apoptotic cells (Annexin V-positive and PI-negative) and late apoptotic or necrotic cells (positive for both PI and Annexin V-FITC staining). Unstained cells and untreated cells were used as negative controls. The data were analyzed using Cyflogic software (non-commercial version, CyFlo Ltd.).

\section{Results}

In the present study we investigated the effect of the overexpression of Egr-1 on the modulation of c-Abl in prostate cancer cells. For this purpose, PC3 and LNCaP prostate carcinoma cells were transfected with a plasmid expressing the Egr-1 cDNA and subjected to clonal selection.

TNF-a strongly induces the expression of Egr-1 and moderately induces the expression of $\mathrm{c}-\mathrm{Abl}$ in PC-3 and LNCaP cells. The expression of Egr-1 and c-Abl protein and mRNA in the
PC-3 and LNCaP cells were evaluated and compared. Proteins from cells were extracted and fractionated by SDS-PAGE. The results revealed that TNF- $\alpha$ caused Egr-1 activation and protein expression in both the PC-3 and LNCaP cells, while the activation of c-Abl was only marginal, when compared to the control cells, suggesting that the effect of TNF- $\alpha$ does not involve the c-Abl pathway (Fig. 1).

Inhibition of EGR-1 suppresses the growth of prostate carcinoma cell lines $P C-3$ and $\mathrm{LNCaP}$, but inhibition of $c-A b l$ expression does not suppress growth. The involvement of Egr-1 and c-Abl was further examined by pre-treatment of cells with siRNA-Egr-1 and Abl inhibitor STI-571, respectively. Egr-1 and c-Abl responses were suppressed in PC-3 and LNCaP prostate carcinoma cell lines (Figs. 2 and 3). As shown by western blot assay, siRNA-Egr-1 was able to strongly suppress the expression of EGR-1 and to moderately suppress the expression of c-Abl in PC-3 (Fig. 2A) and LNCaP cells (Fig. 3A), while inhibition of c-Abl expression by STI-571 treatment did not affect the expression of EGR-1 (Figs. 2A and 3A). To gain further insight into the role of the overexpression of EGR-1 in prostate cells treated either with siRNA-Egr-1 or STI-571, we overexpressed EGR-1 in PC-3 and LNCaP cells and investigated the effect of this overexpression on cell proliferation in cells treated either with siRNA-Egr-1 or STI-571. Figs. 2B and 3B show the results obtained in PC-3 and LNCaP cells after 1, 2 and 3 days of incubation in the presence of siRNA-Egr-1 or STI-571. Cell growth was measured using an MTT assay. A strong anti-proliferative activity was noted following treatment with siRNA-Egr-1, while STI-571 showed only a moderate anti-proliferative effect (Figs. 2B and 3B). In addition, application of TNF- $\alpha$ was unable to increase the cell number in the presence of siRNA-Egr-1 (Figs. 2B and 3B). Notably, cells treated with STI-571 also showed a significant increase in the number of cells, but this number was lower than that in the cells treated with siRNA-Egr-1 both in PC-3 (Fig. 2B) and LNCaP cells (Fig. 3B). The results suggest that overexpression of EGR-1 partially decreased the c-Abl activity in a p53-independent manner since both p53-deficient (PC-3) and wild-type p53 (LNCaP) cells were similarly affected by overexpression of EGR-1. The results seem to contradict previous studies, which found that Abl activation in situ, and elevated phospho-c-Abl are correlated with increased local expression of Egr-1. Collectively, these results position Egr-1 downstream of c-Abl in the fibrotic response.

siRNA-Egr-1 and STI-571 induce apoptosis in PC-3 and LNCaP cells. We investigated the effect of siRNA-Egr-1 and STI-571 on the ability to induce caspase activity in PC-3 and LNCaP cells. Cells overexpressing EGR-1 were treated or not with either siRNA-Egr-1 or STI-571 at the indicated periods of time, and caspase activity was subsequently assessed using DEVD-AFC as a substrate. The induction of DEVDase activity by blocking EGR-1 expression was stronger than that induced by inhibition of c-Abl in prostate carcinoma cell lines PC-3 and LNCaP (Fig. 4A and B). Externalization of phosphatidylserine was also investigated as a parameter for the induction of apoptosis by blocking EGR-1 and c-Abl expression in prostate cancer cells. The appearance of Annexin V-positive (apoptotic) cells was evident after only $1 \mathrm{~h}$ of incubation with 
$\mathbf{A}$

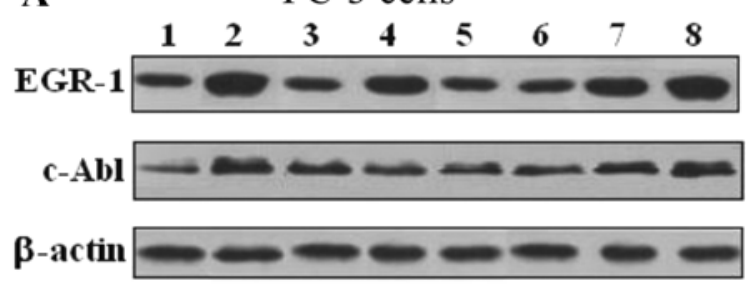

B

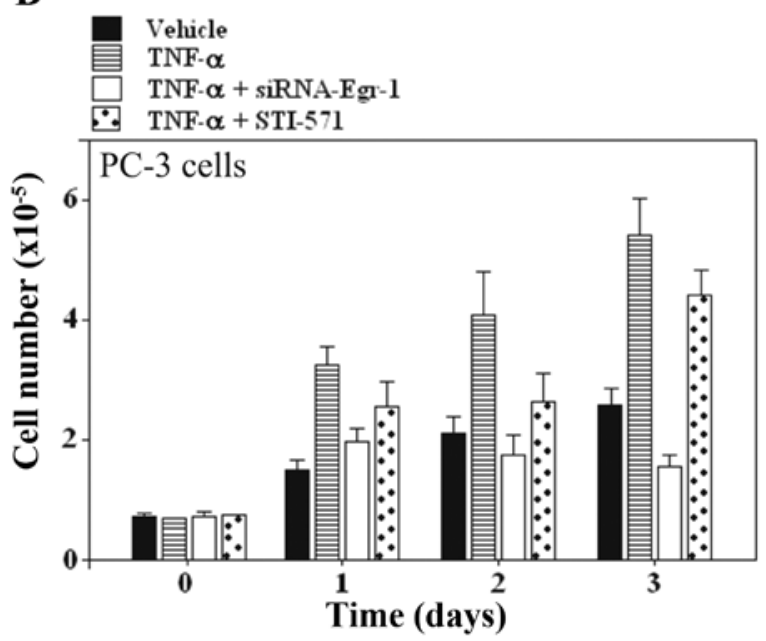

Figure 2. Effect of Egr-1-siRNA and STI-571 on TNF- $\alpha$ stimulated responses in PC-3 prostate carcinoma cells. (A) Expression of EGR-1 and c-Abl in PC-3 prostate cells. Lane 1, untreated cells; lane 2, TNF- $\alpha$; lane 3, siRNA scrambled; lane 4, TNF- $\alpha+$ scrambled; lane 5, Egr-1-siRNA; lane 6, TNF- $\alpha$ + Egr-1-siRNA; lane 7, STI-571; lane 8, TNF- $\alpha$ + STI-571. (B) Proliferation assay in PC-3 cells treated with TNF- $\alpha$ and the combination of TNF- $\alpha$ and Egr-1-siRNA or STI-571. One of 3 similar experiments is shown. EGR-1, early growth response-1; siRNA, small interfering RNA TNF- $\alpha$, tumor necrosis factor $\alpha$; c-Abl, cellular-Abelson tyrosine kinase.

siRNA-Egr-1 and STI-571 and reached a maximum after 3-4 h (Fig. 4C). As expected, the percentage of apoptotic cells was higher in the presence of cells treated with siRNA than the percentage in cells treated with STI-571.

\section{Discussion}

EGR-1 overexpression is a transforming and proliferative signal that contributes to tumor development $(8,9)$ and was firstly characterized as a tumor-suppressor (28). However, recent evidence suggests that EGR-1 can act both as a tumor-suppressor and as a tumor-promoter, depending on the cell type and the context (29). EGR-1 is expressed in limited amounts in normal cells, but is overexpressed in tumors $(30,31)$. Although the mechanisms involved in its overexpression are not clear, it is well known that it enhances resistance to apoptosis in fibrosarcoma, prostate cancer, colon cancer and RAS-transformed cells (32). Further studies have demonstrated that overexpression of EGR-1 in several cancer types directly promotes cancer progression and tumor growth by increasing the expression and secretion of growth factors and cytokines, extracellular matrix proteins and proteases. Similarly, the kinase c-Abl sometimes promotes the development of certain types of cancer and sometimes acts as a suppressor of cancer progression $(23,33)$. The c-Abl protein is
A

LNCaP cells

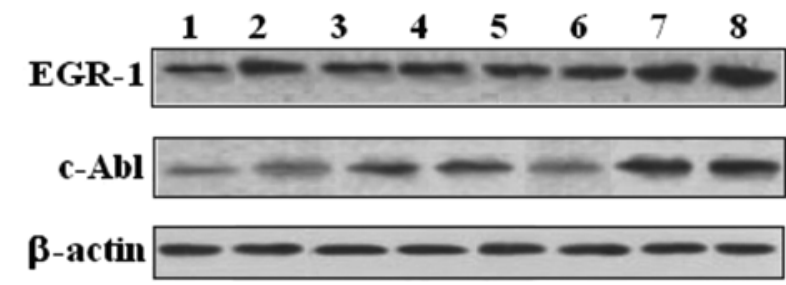

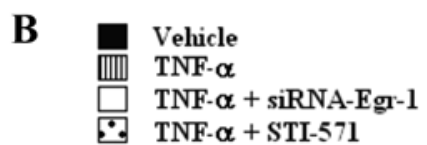

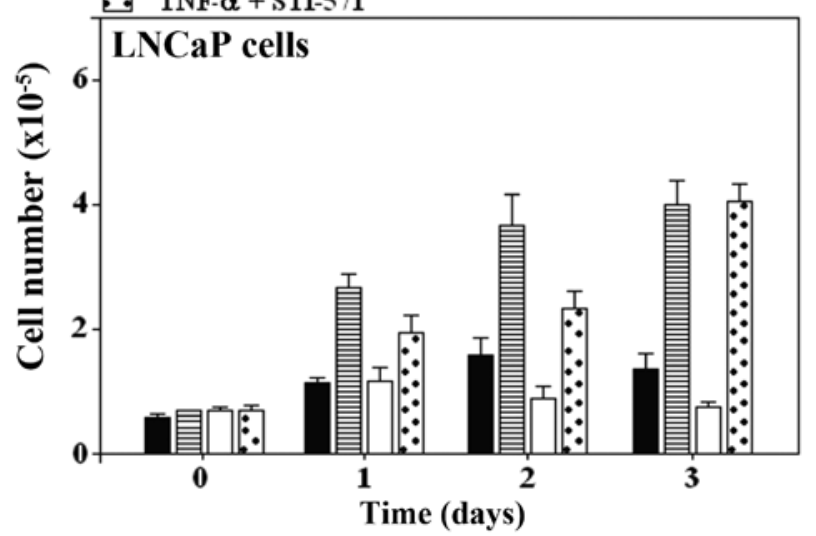

Figure 3. (A) Effect of Egr-1-siRNA and STI-571 on TNF- $\alpha$ stimulated responses in LNCaP prostate carcinoma cells. Expression of EGR-1 and c-Abl in LNCaP prostate carcinoma cell lines. Lane 1, untreated cells; lane 2, TNF- $\alpha$; lane 3, siRNA scrambled; lane 4, TNF- $\alpha+$ scrambled; lane 5, Egr-1-siRNA; lane 6, TNF- $\alpha$ + Egr-1-siRNA; lane 7, STI-571; lane 8, TNF- $\alpha+$ STI-571. (B) Proliferation assay in LNCaP cells treated with TNF- $\alpha$ and the combination of TNF- $\alpha$ and Egr-1-siRNA or STI-571 for the indicated periods of time. One of 3 similar experiments is shown. EGR-1, early growth response-1; siRNA, small interfering RNA; TNF- $\alpha$, tumor necrosis factor $\alpha$; c-Abl, cellular-Abelson tyrosine kinase.

a non-receptor tyrosine protein kinase that is localized in the nucleus and cytoplasm. However, activation of the transforming activity of c-Abl is associated with cytoplasmic localization (34), that sometimes is associated with an unknown tyrosine kinase inhibitor (35). Recent studies indicate that the c-Abl protein is activated by the PDGF3 receptor pathway (36). In these studies, binding of PDGF to the receptor induced c-Src to phosphorylate cytoplasmic c-Abl on tyrosine residues, which led to the activation of c-Abl. In the present study, we investigated whether there are any additional mechanisms by which overexpression of EGR-1 may contribute to tumor development, despite the presence of c-Abl protein, and whether TNF- $\alpha$, an inflammatory cytokine that is found at high levels in cancer, could increase the c-Abl levels. We found that enhancement of EGR-1 levels by transfection of PC-3 and LNCaP cells with a plasmid expressing the wild-type form of the Egr-1 gene was able to increase cell proliferation not only in the absence, but also in the presence of c-Abl. In addition, our results demonstrated that the treatment of PC-3 and LNCaP cells with TNF- $\alpha$ induced an increase in the protein levels of endogenous EGR-1 and c-Abl-1. However, the increase was blocked by a c-Abl-specific inhibitor and did not affect the expression of the overexpressed EGR-1. These results are consistent with those of other studies suggesting that c-Abl-induced apoptosis is partially mitigated by EGR-1 

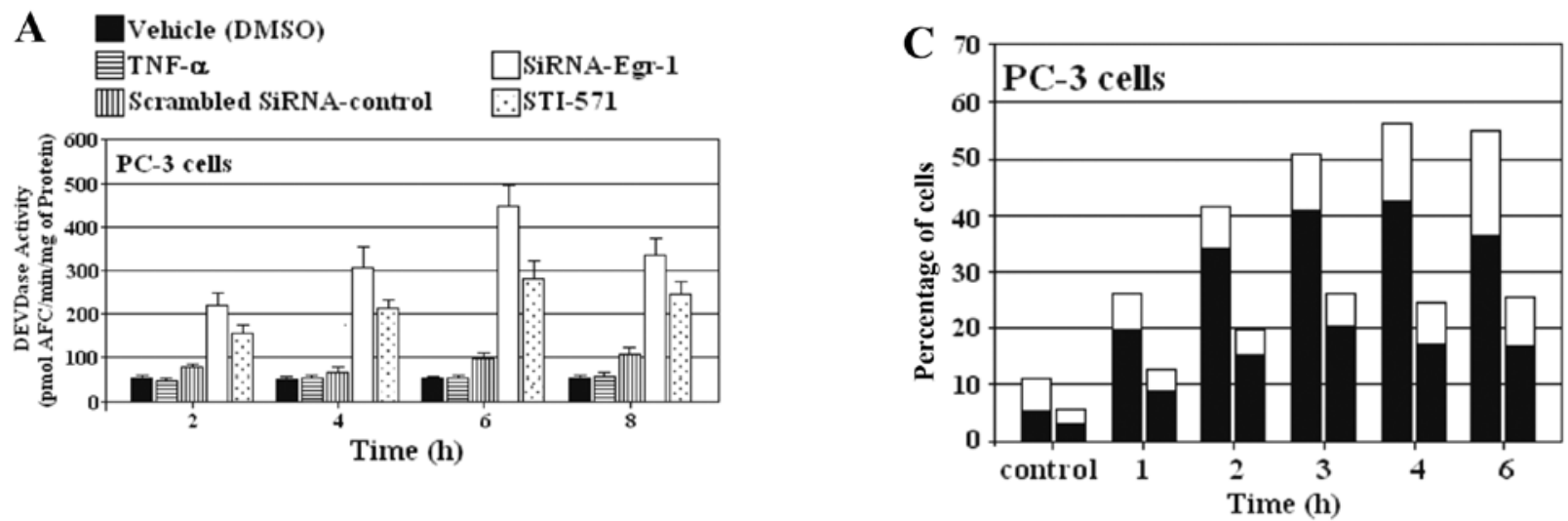

\section{B Vehicle (DMSO) TNF- $\alpha$ 而S Scrambled SiRNA-control $\square$ STI-571}
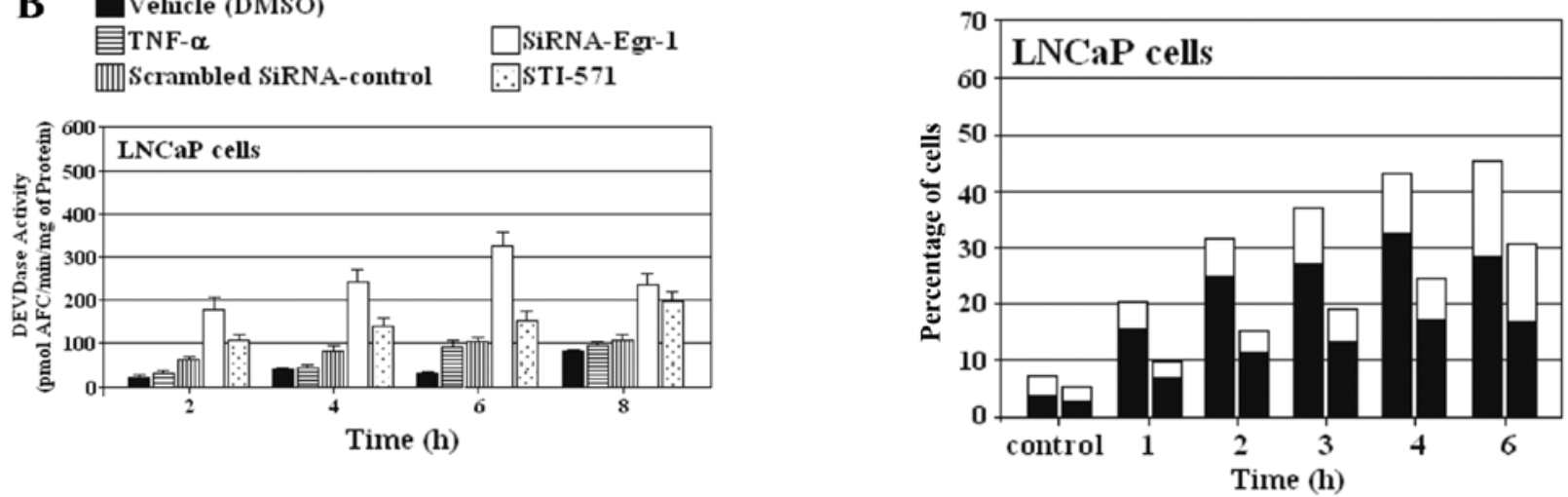

Figure 4. Induction of apoptosis by Egr-1-siRNA and STI-571. (A) Determination of caspase (DEVDase) activity. (A) PC-3 and (B) LNCaP cells were incubated in the presence of Egr-1-siRNA or STI-571 with 10\% FBS for increasing periods of time. Caspase activity was measured using cytosolic extracts and DEVD-AFC as substrate. Cells incubated with vehicle (DMSO) were used as control. The experiment was repeated several times and a representative experiment performed in duplicate is shown. (C) Labelling of apoptotic cells with Annexin V. Cells were incubated with either Egr-1-siRNA (left columns) or with STI-571 (right columns) for the indicated periods of time, and apoptosis was determined by double staining with Annexin V-FITC and PI followed by cytometric analysis. The percentages of Annexin V-positive/PI-negative cells (an indicative of early apoptosis) (black columns) and double-positive cells (late apoptotic and/or necrotic) (white columns) are shown. Cells incubated with vehicle for $1 \mathrm{~h}$ were used as control. A representative experiment performed in triplicate is shown. EGR-1, early growth response-1; siRNA, small interfering RNA; PI, propidium iodide.

activity, as cells devoid of EGR-1 expression undergo reduced rates of c-Abl-induced apoptosis. It is known that EGR-1 mRNA is expressed at higher levels in prostate tumors when compared with that in normal tissues and is correlated with Gleason score (a measure of prostate cancer stage). Moreover, inhibition of EGR-1 expression reverses transformation of prostate cancer cells in vitro and in vivo $(8,9,37)$. Alternatively, forced expression of EGR-1 in non-cancer cells increases proliferation in vitro. In conclusion, we observed that $\mathrm{PC} 3$ and $\mathrm{LNCaP}$ cells overexpressing EGR-1 did not increase the expression of the c-Abl gene or the pro apoptotic activity induced by this kinase. In addition, pre-treatment with the c-Abl (STI-571) inhibitor further increased cell proliferation of PC-3 and LNCaP cells.

\section{Acknowledgements}

We thank Dr Dan Mercola for providing the Egr-1-expression plasmid. The present study was supported by the Laboratory of Experimental Biomedicine, Campus Esmeralda-Iquique, University of Tarapaca, Iquique, Chile.

\section{References}

1. American Cancer Society: Cancer Facts \& Figures 2003. American Cancer Society, Atlanta, GA, 2003.
2. Quinn M and Babb P: Patterns and trends in prostate cancer incidence, survival, prevalence, and mortality. Part I: international comparisons. BJU Int 90: 162-173, 2002.

3. Grönberg H: Prostate cancer epidemiology. Lancet 361: 859-864, 2003.

4. Kaufmann K and Thiel G: Epidermal growth factor and plateletderived growth factor induce expression of $E g r-1$, a zinc finger transcription factor, in human malignant glioma cells. J Neurol Sci 189: 83-91, 2001.

5. Kaufmann K and Thiel G: Epidermal growth factor and thrombin induced proliferation of immortalized human keratinocytes is coupled to the synthesis of Egr-1, a zinc finger transcriptional regulator. J Cell Biochem 85: 381-391, 2002.

6. Liu C, Rangnekar VM, Adamson E and Mercola D: Suppression of growth and transformation and induction of apoptosis by EGR-1. Cancer Gene Ther 5: 3-28, 1998.

7. Parra E, Ferreira $\mathbf{J}$ and Saenz L: Inhibition of Egr-1 by siRNA in prostate carcinoma cell lines is associated with decreased expression of AP-1 and NF- $\kappa$ B. Int J Mol Med 28: 847-853, 2011.

8. Parra E, Ferreira J and Ortega A: Overexpression of EGR-1 modulates the activity of NF- $\kappa \mathrm{B}$ and AP-1 in prostate carcinoma PC-3 and LNCaP cell lines. Int J Oncol 39: 345-352, 2011.

9. Parra E, Ortega A and Saenz L: Downregulation of Egr-1 by siRNA inhibits growth of human prostate carcinoma cell line PC-3. Oncol Rep 22: 1513-1518, 2009.

10. Lee CG, Cho SJ, Kang MJ, Chapoval SP, Lee PJ, Noble PW, Yehualaeshet T, Lu B, Flavell RA, Milbrandt J, Homer RJ and Elias JA: Early growth response gene 1-mediated apoptosis is essential for transforming growth factor $\beta_{1}$-induced pulmonary fibrosis. J Exp Med 200: 377-389, 2004.

11. Parra E and Ferreira J: The effect of siRNA- Egr-1 and camptothecin on growth and chemosensitivity of breast cancer cell lines. Oncol Rep 23: 1159-1165, 2010. 
12. Baron V, Adamson ED, Calogero A, Ragona G and Mercola D: The transcription factor Egr1 is a direct regulator of multiple tumor suppressors including TGF $\beta 1$, PTEN, p53 and fibronectin. Cancer Gene Ther 13: 115-124, 2006.

13. Shaul $\mathrm{Y}$ and Ben-Yehoyada M: Role of $\mathrm{c}-\mathrm{Abl}$ in the DNA damage stress response. Cell Res 15: 33-35, 2005.

14. Kharbanda S, Ren R, Pandey P, Shafman TD, Feller SM, Weichselbaum RR and Kufe DW: activation of the c-Abl tyrosine kinase in the stress response to DNA-damaging agents. Nature 376: 785-788, 1995.

15. Pandey P, Raingeaud J, Kaneli M, Weichselbaum RR, Davis RJ, Kufe D and Kharbanda S: Activation of p38 mitogen-activated protein kinase by c-Abl-dependent and independent mechanisms. J Biol Chem 271: 23775-23779, 1996.

16. Cong F and Goff SP: c-Abl-induced apoptosis, but not cell cycle arrest, requires mitogen-activated protein kinase kinase 6 activation. Proc Natl Acad Sci USA 96: 13819-13824, 1999.

17. Stuart JR, Kawai H, Tsai KK, Chuang EY and Yuan ZM: c-Abl regulates early growth response protein (EGR1) in response to oxidative stress. Oncogene 24: 8085-8092, 2005.

18. Daniels CE, Wilkes MC, Edens M, Kottom TJ, Murphy SJ, Limper AH and Leof EB: Imatinib mesylate inhibits the profibrogenic activity of TGF- $\beta$ and prevents bleomycin-mediated lung fibrosis. J Clin Invest 114: 1308-1316, 2004.

19. Welch PJ and Wang JY: Abrogation of retinoblastoma protein functions by c-Abl through tyrosine kinase-dependent and -independent mechanisms. Mol Cell Biol 15: 5542-5551, 1995.

20. Barilà D, Rufini A, Condò I, Ventura N, Dorey K, Superti-Furga G and Testi R: Caspase-dependent cleavage of c-Abl contributes to apoptosis. Mol Cell Biol 23: 2790-2799, 2003.

21. Machuy N, Rajalingam K and Rudel T: Requirement of caspasemediated cleavage of c-Abl during stress-induced apoptosis. Cell Death Differ 11: 290-300, 2004.

22. Huang DY, Chao Y, Tai MH, Yu YH and Lin WW: STI571 reduces TRAIL-induced apoptosis in colon cancer cells: c-Abl activation by the death receptor leads to stress kinase-dependent cell death. J Biomed Sci 19: 35, 2012.

23. Li B, Cong F, Tan CP, Wang SX and Goff SP: Aph2, a protein with a $z$-DHHC motif, interacts with c-Abl and has pro-apoptotic activity. J Biol Chem 277: 28870-28876, 2002.

24. Abdulkadir SA, Carbone JM, Naughton CK, Humphrey PA, Catalona WJ and Milbrandt J: Frequent and early loss of the EGR1 corepressor NAB2 in human prostate carcinoma. Hum Pathol 32: 935-939, 2001.

25. Lucerna M, Mechtcheriakova D, Kadl A, Schabbauer G, Schäfer R, Gruber F, Koshelnick Y, Müller HD, Issbrücker K, Clauss M, Binder BR and Hofer E: NAB2, a corepressor of EGR-1, inhibits vascular endothelial growth factor-mediated gene induction and angiogenic responses of endothelial cells. J Biol Chem 278: 11433-11440, 2003.
26. Parra E: Inhibition of JNK-1 by small interference RNA induces apoptotic signalling in PC-3 prostate cancer cells. Int J Mol Med 30: 923-930, 2012

27. Parra E and Gutiérrez L: Growth inhibition of Tax-activated human Jurkat leukemia T cells by all-trans retinoic acid requires JNK-1 inhibition. Oncol Rep 29: 387-393, 2013.

28. Krones-Herzig A, Mittal S, Yule K, Liang H, English C, Urcis R, Soni T, Adamson ED and Mercola D: Early growth response 1 acts as a tumor suppressor in vivo and in vitro via regulation of p53. Cancer Res 65: 5133-5143, 2005.

29. Calogero A, Arcella A, De Gregorio G, Porcellini A, Mercola D, Liu C, Lombari V, Zani M, Giannini G, Gagliardi FM, Caruso R, Gulino A, Frati L and Ragona G: The early growth response gene $E G R-1$ behaves as a suppressor gene that is down-regulated independent of $\mathrm{ARF} / \mathrm{Mdm} 2$ but not p53 alterations in fresh human gliomas. Clin Cancer Res 7: 2788-2796, 2001.

30. Egerod FL, Bartels A, Fristrup N, Borre M, Ørntoft TF, Oleksiewicz MB, Brünner N and Dyrskjøt L: High frequency of tumor cells with nuclear Egr-1 protein expression in human bladder cancer is associated with disease progression. BMC Cancer 9: 385, 2009.

31. Svaren J, Ehrig T, Abdulkadir SA, Ehrengruber MU, Watson MA and Milbrandt J: EGR1 target genes in prostate carcinoma cells identified by microarray analysis. J Biol Chem 275: 38524-38531, 2000.

32. Gitenay D and Baron VT: Is EGR1 a potential target for prostate cancer therapy? Future Oncol 5: 993-1003, 2009.

33. Suzuki J, Sukezane T, Akagi T, Georgescu MM, Ohtani M, Inoue H, Jat PS, Goff SP, Hanafusa $\mathrm{H}$ and Shishido T: Loss of $c$ - $a b l$ facilitates anchorage-independent growth of $\mathrm{p} 53-$ and RB-deficient primary mouse embryonic fibroblasts. Oncogene 23 : 8527-8534, 2004.

34. Taagepera S, McDonald D, Loeb JE, Whitaker LL, McElroy AK, Wang JY and Hope TJ: Nuclear-cytoplasmic shuttling of C-ABL tyrosine kinase. Proc Natl Acad Sci USA 95: 7457-7462, 1998.

35. Ling X, Ma G, Sun T, Liu J and Arlinghaus RB: Bcr and Abl interaction: oncogenic activation of c-Abl by sequestering Bcr. Cancer Res 63: 298-308, 2003.

36. Furstoss O, Dorey K, Simon V, Barilà D, Superti-Furga G and Roche S: c-Abl is an effector of Src for growth factor-induced c-myc expression and DNA synthesis. EMBO J 21: 514-524, 2002.

37. Baron V, De Gregorio G, Krones-Herzig A, Virolle T, Calogero A, Urcis R and Mercola D: Inhibition of Egr-1 expression reverses transformation of prostate cancer cells in vitro and in vivo. Oncogene 22: 4194-4204, 2003. 